\title{
Od rozmowy do słownika. Słownik gwarowy jako efekt współpracy szkoły i uniwersytetu
}

\author{
From conversation to dictionary. Dialect dictionary \\ as a result of cooperation between the school \\ and the university
}

\author{
Błłażej Osowski \\ Uniwersytet im. Adama Mickiewicza w Poznaniu
}

\begin{abstract}
The article describes the possibility of a project activity - creating a school dialect dictionary. Attention was drawn to the importance of regional education and dialect as a component of regional culture. Also described are the students' preparations for the project, specific solutions adopted in the dictionary (the way of writing, entry structure), the use of work effects (dictionary) in the school didactics.
\end{abstract}

Key words: dialect, dialect dictionary, lexis, regional culture

Streszczenie: W artykule opisano możliwość działania projektowego - stworzenia szkolnego słownika gwarowego. Zwrócono uwagę na znaczenie edukacji regionalnej oraz gwar jako składnika kultury regionalnej. Opisano także przygotowanie uczniów do projektu, konkretne rozstrzygnięcia przyjęte w słowniku (sposób zapisu, budowa hasła), wykorzystanie efektów pracy (słownika) w dydaktyce szkolnej.

Słowa kluczowe: gwara, słownik gwarowy, leksyka, kultura regionalna

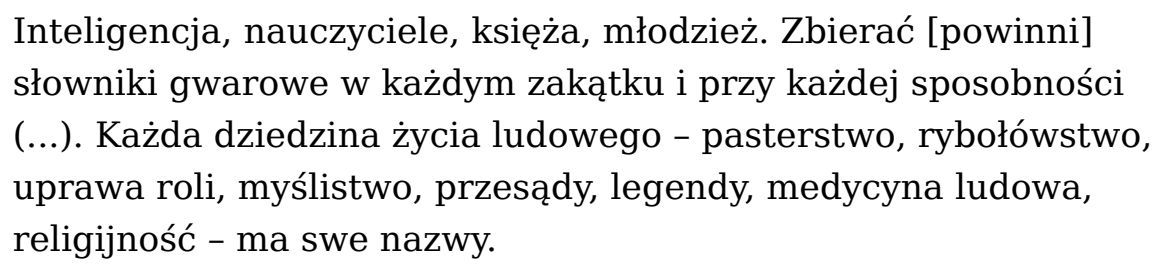

(Żeromski 2000, 82)

Słownik gwarowy wśród innych typów opracowań leksykograficznych zajmuje specjalne miejsce. Słowniki poprawnej polszczyzny, frazeologiczne, etymologiczne itd. powstają jako wynik wytężonej pracy ze słowem pisanym. Materiału do słownika gwarowego dostarcza spotkanie dwóch ludzi - rozmowa, którą przeprowadzić może każdy, jeśli otrzyma kilka podpowiedzi. Niniejszy tekst opisuje, jak od rozmowy ucznia z babcią, 
dziadkiem, starszymi sąsiadami możemy doprowadzić do powstania słownika gwarowego opracowywanego przy współudziale dwóch środowisk - szkoły i uniwersytetu ${ }^{1}$. Koncepcję tę w Wielkopolsce od lat rozwija Jerzy Sierociuk (Sierociuk 2002, 2006, 2010), ale jak pokazuje motto ze Snobizmu i postępu, ma ona o wiele dłuższą tradycję. Najpierw krótko omówię rolę kultury regionalnej w edukacji szkolnej, ze szczególnym uwzględnieniem jej niezwykle ważnego składnika (gwary), a następnie przejdę do możliwości powstania szkolnego słownika gwarowego.

Nie chciałbym, aby przy lekturze niniejszego artykułu powstało wrażenie przeciwstawienia kultury ogólnej i regionalnej, polszczyzny ogólnej i gwary. Są to dwa bieguny tego samego zjawiska (kultury, języka) - raz jesteśmy bliżsi jednemu, raz drugiemu, niemal nigdy nie osiągając całkowicie tylko jednego punktu skrajnego ${ }^{2}$.

Przed przejściem do meritum sprawy muszę zaznaczyć, że rzeczywistość językowa współczesnej wsi to nie tylko gwara. Przemiany społeczne, gospodarcze i cywilizacyjne doprowadziły do stanu, w którym gwara jest tylko jedną z odmian języka używanych na wsi. Mieszkańcy wsi najczęściej posługują się mieszaniną gwary i języka ogólnego ${ }^{3}$, co skłoniło Sierociuka do wprowadzenia terminu „język mieszkańców wsi” (Sierociuk 2007), obejmującego elementy tradycyjnej gwary, potoczne i ogólne, których pojawianie się jest uwarunkowane socjologicznie (ze względu na wiek, płeć, zawód itd.).

\section{Edukacja regionalna i gwary w szkole}

W dobie intensywnych procesów globalizacji, standaryzacji i homogenizacji, szybko zmieniających się warunków życia, makdonaldyzacji kultury popularnej kulturę regionalną traktuje się jako bufor chroniący mieszkańców przed utratą osobistej tożsamości i działaniem różnorodnych stresów związanych z wymienionymi procesami (Kowalik 2006, 30; Podemska-Kałuża 2010, 167).

Świadome odwoływanie się do swoich korzeni kulturowych oraz wiedza o tym, skąd pochodzimy, przyczyniają się do ocalania i trwania elementów dziedzictwa kulturowego (...). Każdy z nas ma możliwość stać się lokalnym animatorem kultury, dbać o te elementy kultury, które nadal funkcjonują i pamiętać o tych, które już zanikły (Brzezińska 2006, 187).

${ }^{1}$ Form współpracy tych dwóch środowisk jest oczywiście więcej, np. pogadanki gwaroznawców w szkołach, wycieczki, obozy wędrowne, obozy stacjonarne, korespondencyjne wypełnianie ankiet i sporządzanie nagrań (Falińska 2007, 75).

2 Trafnie pisze o tym Jadwiga Wronicz przy okazji omawiania stereotypu gwary w Polsce: „Należałoby raczej powiedzieć, że cechy gwarowe występują w mowie ludzi wykształconych i mieszkających w mieście w mniejszym nasileniu [niż na wsi - B.O.]. Nieuzasadnione jest także ograniczanie funkcji gwary do komunikacji w najprostszych sytuacjach życiowych" (Wronicz 2013, 234).

3 Zadaniem szkoły nie powinna być eliminacja gwary, lecz uporządkowanie relacji między odmianami. „Należy uświadamiać uczniom, że gwara jest jedną z odmian języka, odmianą pełnoprawną, nie gorszą, że chodzi tylko o to, by tymi dwoma odmianami posługiwać się w różnych sytuacjach. Z punkty widzenia kultury języka sytuacje oficjalne, kontakty zewnętrzne wymagają języka ogólnego, w kontaktach rodzinnych, sąsiedzkich, rówieśniczych gwara spełnia bez problemu funkcję komunikacyjną, nieraz nawet lepiej niż język ogólny” (Grabka, Kucharzyk 2007, 69). 
Jednak zwrócenie się ku kulturze regionalnej, dobrze znanej uczniom od dzieciństwa, może nie tylko przywrócić poczucie posiadania swojego miejsca na ziemi, ale przez poznanie tradycji innych regionów pokazać postawę tolerancji wobec różnorodności. Należy podkreślić, że edukacja regionalna nie jest przejawem partykularyzmu, przedkładaniem interesów lokalnych nad ogólne.

Edukacja regionalna i edukacja patriotyczna to dwie prawie nierozłączne ścieżki, (...) dobrze przygotowane programy edukacji o regionie i patriotyzmie oraz ich realizacja przez szkoły - może wyprowadzić w świat tolerancyjnego obywatela i patriotę, świadomego swej odmienności narodowej i kulturowej, ale jednocześnie przejawiającego tolerancję wobec innych narodów i kultur (Ambroziak, Buchali, Czarnek, Olszewska 2010, 219).

Treści regionalne w polskiej szkole pojawiają się od dawna w różnych formach. Od roku 1999 istniała możliwość wyboru ścieżki edukacyjnej Edukacja regionalna - dziedzictwo kulturowe $w$ regionie, zadania o podobnym charakterze realizowane były również w ramach projektów edukacyjnych w gimnazjach (Wołek 2011, 60). Uczniowie poznają gwary przy okazji tematów o stylizacji, zróżnicowaniu odmian polszczyzny. W dużej mierze jednak jest to kontakt nie z żywym językiem, lecz jego formą pisaną (stylizowaną) lub teorią. Tworzenie słownika gwarowego włącza uczniów i nauczycieli do czynnego udziału w proces naukowy i pozwala obcować z żywym słowem mówionym.

Jak pokazują badania Anny Podemskej-Kałuży, młodzież nie dyskredytuje rangi edukacji regionalnej i znaczenia procesu poszukiwania tożsamości kulturowej. Krytycznie ocenia natomiast metody i formy pracy dydaktycznej, np. licealiści zwracali uwagę, że w praktyce nie różnicuje się oferty edukacyjnej ze względu na wiek uczniów (Podemska-Kałuża 2010, 172). Szkolny słownik gwarowy jest zadaniem, które najlepiej odpowiada możliwościom rozwojowym uczniów szkół średnich (zwłaszcza jeśli obuduje się go treściami teoretycznymi, jak pochodzenie polskiego języka literackiego i udział poszczególnych dialektów w kształtowaniu tej odmiany polszczyzny, uwarunkowania historyczne, geograficzne i językowe cech gwarowych, obecność gwary w popkulturze, reklamie i muzyce). W tym przypadku większy może też być udział uczniów na poszczególnych etapach powstawania słownika (opis historii miejscowości, zebranie potrzebnych fotografii itp.). Efektem współpracy ze szkołami średnimi są dwa słowniki z terenu powiatu kolskiego (Osowski 2018a, Osowski 2018b) i publikacja dotycząca ziemi łukowskiej (Sierociuk 2019). Jednak również młodsi uczniowie szkoły podstawowej świetnie spisują się przy współpracy nad słownikiem gwarowym (oczywiście treści teoretyczne mają tu mniejszy udział), czego dowodzą słowniki okolic Gniezna (Kobus, Gniazdowski 2018, Kobus, Stępień 2018).

Edukacja regionalna to nie tylko działanie dydaktyczne, lecz także część innego ważnego zadania szkoły - procesu wychowawczego. 
Stopień utożsamiania się z własnym narodem i jego kulturą, zarówno w wymiarze ogólnym, jak i regionalnym, jest zależny od wrażliwości danej osoby na wartości tej kultury. Nie można tej wrażliwości ani nakazać, ani zabronić. Można ją natomiast kształtować i jest to zadanie szkoły (Wronicz 2013, 235).

Ten rodzaj edukacji integruje społeczność lokalną i przyczynia się do budowania społeczeństwa obywatelskiego (Wołek 2011, 66). Jednocześnie rozwijanie kultury regionalnej przyczynić się może do wzrostu prestiżu społecznego danej społeczności lokalnej. Gwara staje się czymś, co stanowi o odrębności, oryginalności danej miejscowości, czym można się pochwalić wobec innych. To z kolei zwiększa poczucie identyfikacji z miejscem zamieszkania i regionem, dochodzi do silnej integracji członków społeczności (Kowalik 2006, 23).

Zwraca się także uwagę, że gwara ma duże znaczenie $\mathrm{w}$ tworzeniu więzi rodzinnych, lokalnych, regionalnych. W ustnych, gwarowych przekazach ożywają dawne realia najbliższego otoczenia, minionych pokoleń (ludzi i wydarzeń), obyczajowości.

W dialogu i współdziałaniu członków rodziny wytwarzają się więzi międzypokoleniowe, które łączą dziadków, rodziców i dzieci, prowadzą młodych ludzi do rozumienia własnej tożsamości i kształtują poczucie przynależności regionalnej (Synowiec 2013, 151).

Punktem wyjścia jest tu rozmowa, od której zaczyna się także praca nad słownikiem.

Na koniec rozważań teoretycznych kilka słów o związkach języka i kultury regionalnej. Dziedzictwo kulturowe podzielić można na materialne oraz niematerialne/duchowe/społeczne (Jędrysiak 2010, 38). Język łączy obie części: przedmioty, zjawiska, obyczaje typowe dla kultury wsi zyskują charakterystyczne, lokalne nazwy, np. wielkopolski przysmak z białego sera doprawionego cebulką, śmietaną, solą i pieprzem w regionie tym nazywany jest powszechnie gzikiem lub gzika. W edukacji regionalnej nie sposób oddzielić płaszczyzny językowej od kontekstu kulturowego, gwary są bowiem nieodłącznym elementem kulturowego dziedzictwa regionów. To za ich sprawą możliwe jest przekazywanie i utrwalanie kultury (Synowiec 2013, 141).

\section{Słownik gwarowy}

Terytorialne odmiany polszczyzny cechuje bogactwo leksykalne. Gwara nastawiona jest na „konieczność nazwania każdego najdrobniejszego elementu otaczającej rzeczywistości" (Pelcowa 2013, 219). Bogactwo środków wyrazu zauważał również Stefan Żeromski, który myślał o jego wykorzystaniu dla pomnożenia zasobów leksykalnych polszczyzny literackiej . Celem

\footnotetext{
4 „Nowością niewątpliwą w dziedzinie literatury byłoby wzbogacenie jezzyka co najmniej dziesięciokrotnie słownictwem gwarowym i starem, nazywającym po imieniu dziesięciokroć od naszego obszerniejszy zasób rzeczy, zjawisk, pojęć i czynności, ruchów i odczuwań, które człowiek naszego rodu przez tyle wieków w walce $\mathrm{z}$ dziką przyrodą i w trudzie niezmiernym utworzył, wciągając do swojej mowy nazwy tych rzeczy i pojęć" (Żeromski 2000, 85).
} 
słownika gwarowego jest natomiast udokumentowanie i zachowanie dla przyszłych pokoleń dzisiejszego stanu języka wsi.

Współpraca środowiska uniwersyteckiego i szkolnego wymaga przyjęcia kilku rozwiązań:

1. Przygotowanie uczniów. Choć uczniowie, jako członkowie danej społeczności, posiadają niewątpliwe atuty w postaci znajomości środowiska, realiów, łatwego dostępu do rozmówców ${ }^{5}$, to jednak mogą nie orientować się w szczegółach dawnego życia na wsi, o które często pyta się w wywiadach dialektologicznych. Z pomocą przychodzą przygotowane w Pracowni Dialektologicznej UAM kwestionariusze tematyczne (Sierociuk 2002), czyli zbiory pytań skupionych wokół centralnego zagadnienia, np. chrzest, dom, kuchnia, Wielkanoc, Boże Narodzenie itd. ${ }^{6}$. Szkoła współpracująca z Pracownią otrzymuje taką swoistą mapę zagadnienia, która kieruje od jednego szczegółowego pytania do drugiego, dzięki czemu nawet osoba bez przygotowania etnograficznego potrafi przeprowadzić wywiad. Pytania dotyczące domu - jego budowy i wyposażenia - mogą wyglądać tak:

36. Pomieszczenie, w którym przechowywano m.in. zapasy żywności? (komora)

37. Czy komora miała okno?

38. Mały pokoik, obok pokoju głównego (alkierz, anklirz)

39. Wychodząc z domu (np. do pracy w pole), należało ten dom... (zamknać, zakluczyć, przekluczyć)

40. Gdy gospodarze pracowali w polu, to dom był ... (zamknięty, zakluczony)

41. Jakie były sposoby „zamykania” pomieszczeń? (np. zamki metalowe, kłódki, inne ...)

42. Pomieszczenie (pokój) w domu, w którym się jada? (jadalka // jadalnia) ${ }^{7}$

Kwestionariusz, jak widać, poza pytaniami zawiera również w nawiasie ewentualne odpowiedzi, choć może się zdarzyć, że pojawią się odpowiedzi spoza propozycji. Ważne jest, by rozmówcy dać czas na dłuższą odpowiedź, ponieważ wtedy w wypowiedziach mają szanse wystąpić ciekawe szczegóły, np. przy okazji pytań o kuchnię zanotowano w Tarnówce (pow. kolski):

ale to była kiedyś kuchnia to ... to zastempowało ... dużo dużo rzeczy ... co dzisiaj sie nazywa ... jes co innego ... bo nieraz nawet kuchnia była niby że kuchnia ale i było sypialnio ${ }^{m}$ bo ... ludzie nie mieli takych ... tyle mieszkań co dzisiaj jes ... że każdy ma swoje mieszkanie ... swój pokój ...

Kuchnia jest zresztą jednym z łatwiejszych tematów do odpytania i do przygotowania w postaci słownika. Cóż bowiem bliższego człowiekowi niż jedzenie? A ponadto kuchnia domowa to nie tylko przepisy konkretnych dań, ale również wspomnienia osób, które te

\footnotetext{
${ }^{5}$ Jadwiga Wronicz podkreśla łatwość autochtona w badaniu lokalnego słownictwa, ponieważ rozmówcy (krewni, znajomi) uważają go „za swojego”, mówiącego tutejszym językiem (Wronicz 2007, 90).

6 Przykłady kwestionariuszy znaleźć można na stronie http://dialektologia.amu.edu.pl/zbieraczeslow.htm i http://dialektologia.amu.edu.pl/gwaranaszakochana.htm.

${ }^{7}$ http://dialektologia.amu.edu.pl/teksty/dom1.pdf.
} 
dania przyrządzały. Jedno pytanie o naworkę wywołało całą długą wypowiedź:

naworka to po prostu na wodzie było gotowane i zalewane mlykim ... robiło sie kruszanki ... no to kruszanki to już po prostu ... na jajku sie takie te ... kluszeczki i to sie zalewało te ... banie sie gotowało ... równiż sie zalywało mlykim ... no ... no mleko sie przegotowało i zaś sie banie ugotowało ... jóm sie osłodziło ${ }^{u}$ osolyło ... i potym ... takie kluski były ... co sie nazywały goloki ... nie wim czy może pan $w$ dómu słyszoł tyle ... tarte kartofle tak cin żko "odciśninte ... że nie musiało być nic ... i to ciasto tylko sie ukulało na ry ${ }^{n} c e$... i to takie ... goloki były do ty[j] bani ... a juz tero późni to juz ... kruszónki tyż robili albo ... makarón bo już tero wychodzi to ... stare ludzie to ... mieli na wszysko czaz i zrobili ... a tero to młodym to sie tegó nie chce robić a... (Spławie, pow. koniński).

Rozmowy są nagrywane. W czasach powszechności telefonów komórkowych nie stanowi to problemu.

2. Sposób zapisu. Nagrany wywiad uczniowie dostarczają pracownikom Pracowni Dialektologicznej, gdzie następuje jego transkrypcja ${ }^{8}$. Ze względu na fakt, że słownik ma służyć lokalnej społeczności, zrezygnowano z zapisu za pomogą alfabetu fonetycznego. Zapis oparto na ortografii ogólnopolskiej, ale z oddaniem cech gwarowych (Kąś 1998, 232-234). Długie wypowiedzi można wykorzystać do tworzenia haseł słownikowych z ciekawymi cytatami, przykładami użycia danego wyrazu. Ponadto wypowiedź taka staje się swoistą historią, wejrzeniem w młodość opowiadającego, świadectwem jego życia, np.

moja babcia przed wojnóm i dziadek to chodzili do Czynstochowy na pieszo ... to jak to kiedyś to babcia mówiła że bochynek chleba ... i ... i garnek taki jak to były garki takie ... polewane ... (...) i taka torba i kij na plecach i śli do Czyn stochowy to ... dwa tygodnie śli $w$ jednóm stróne i dwa tygodnie ... w drugóm to na wiosne to sie spieszyli żeby zasadzić ... kartofle ... porobić wszysko $w$ polu bo jedyn roku szła ... babcia a na drugi dziadek ... i tego ... i ... to takóm grubóm $^{m}$ ksión żke miała tych pieśni pontniczych ... i ... babcia mówi ... tak ty"gachno śpiewali jak to przód tag mówili ... nie? ... nie mocno tyko ty go ... tak ty gachno śpiewali ... (Spławie, pow. koniński).

Prowadzenie wywiadu umożliwiającego „wygadanie się” rozmówcy sprawia, że dialektologia pokazuje świat mieszkańców wsi, oddaje im głos (często niesłyszany przez innych członków społeczności), stawia w centrum zainteresowania (Osowski 2016, 89). Badania naukowe zyskują ludzki wymiar.

3. Hasło słownikowe. Leksykografowie opracowujący regionalne słowniki gwarowe zwracają uwagę na - omówiony powyżej - związek języka $\mathrm{z}$ lokalną kulturą. Tym samym treści etnograficzne przejawiać się mogą na kilka sposobów: a) w definicji (Kąś 2009, 14), b) przez bogatą ilustrację tekstową hasła, tj. dużą liczbę cytatów i długie cytaty (Karaś

${ }^{8}$ Dzięki możliwościom współczesnej techniki przekazanie nagrania może odbyć się za pomocą Internetu przez wysłanie na adres: zbieraczeslow@gmail.com. 
2013, 211), c) przez ilustracje pokazujące najważniejsze elementy kultury materialnej (Kąś 2009, 17; Karaś 2013, 211). Poniższe grafiki prezentują podpunkty b) i c).

LEKIE, LEKKIE, LETKIE - 'narząd oddechowy - płuca; też: wykorzystywany jako podroby': lekie to [j]es[t] płuca ... od świni ... (Stary Budzisław); o! kaszanke sie robi w inny sposób ... kaszanka to won troba ... sie kładzie to lekkie ... to znaczy te płuca ... no $i$ wtedy ... kawalki miensa ... czy nawed o! jak sie nie robi salsesonu to ta głowa idzie na ... i wszysko sie gotuje ... (Stary Budzisław); lekie lekie ... co to je? ... wiem ale nie potrafie dokładnie tego ... opisać ... to so ${ }^{m}$ pluca chyba ... to so ${ }^{m}$ chyba pluca świni to mówióm lekie ... (Babiak); lekkie ... mie ${ }^{n}$ so letkie czy jakoś ... letkie ... płuca to letkie ... (Felicjanów); [R1:] to-s wóntroba ... letkie sie myli ... [R2:] gotuje sie najpierw ... [R1:] gotuje sie a potem sie myli ... to przez maszynke ... i sie wkłodo $w$ kasze ... [R2:] krew ... [R3:] [...] krew i sie znowu napycha ... [R2:] i może być kasza...anka ... ta z tyj zwykłej kaszy i... [R3:] taterczy ... (Felicjanów); lekie ... letkie ... (Rzuchów); płuca so ${ }^{m}$ letkie ... (Rzuchów); lekkie ... (Koło).

Przykład hasła LeKIE, LeKKIE, LETKIE (Osowski 2018a).

ŻUROWNIK - 'specjalny, gliniany garnek, w którym kiszono żur': [R1:] to sie brało món $^{n} k i$ wody ... [R2:] żytnióm ${ }^{m}$... [R1:] żytni $m^{n}{ }^{n} k i$... i sie zarobiało ... w takim żurowniku ... i sypało sie món ${ }^{n}$ e wode i sie tam ... w tym żuro... w tym ... koziołkim kry $y^{\text {ciało }}$ ... i sie przykrywało ... stowiało sie na kuchni czy na piecu ... [R2:] aż zakisło to ... dopiero gotowano żur... (Felicjanów); 47. 


\section{7. ŻUROWNIK}

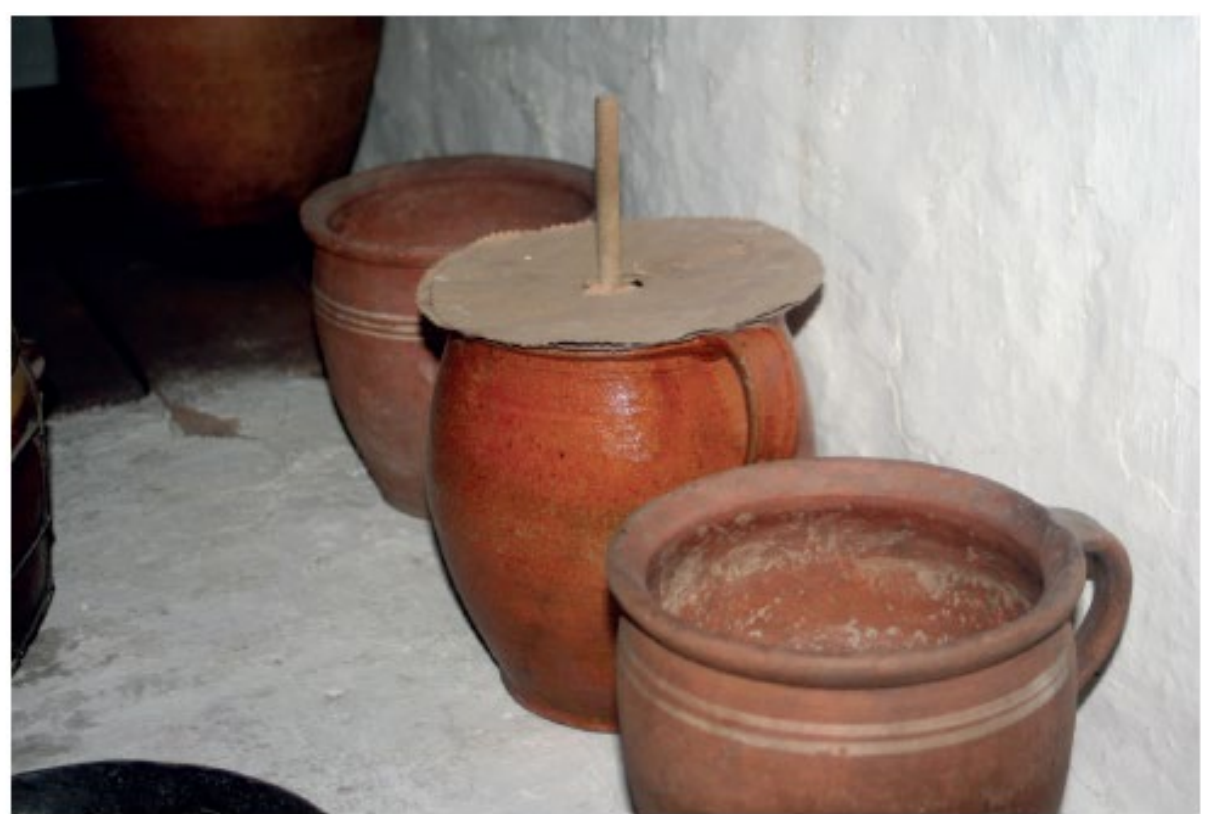

Przykład hasła żurownIK i ilustracja zdjęciowa (Osowski 2018b)

4. Wykorzystanie efektów pracy (słownika). Powstały przy współpracy uczniów i nauczycieli gwarowy słownik oddziałuje wielorako. W dydaktyce szkolnej słownik gwarowy:

- jest źródłem cech gwarowych, które omówić można przy okazji tematów o zróżnicowaniu terytorialnym polszczyzny (język ogólny - dialekty - gwary - język regionalny), zjawiskach fonetycznych (m.in. uproszczenia i upodobnienia artykulacyjne) czy procesach historycznych zachodzących w polszczyźnie (samogłoski pochylone, archaiczne końcówki fleksyjne itd.),

- daje możliwość przyjrzenia się zjawiskom charakterystycznym dla mówionej odmiany języka, np. synonimii, okazjonalnym formacjom słowotwórczym (np. budować - ubudować), swobodniejszemu ukształtowaniu składniowemu wypowiedzi (liczne powtórzenia, zdania niedokończone, niekonsekwencje gramatyczne),

- jest źródłem informacji o charakterze etnograficznym, które wykorzystać można dla zapoznania uczniów z kulturą tradycyjną (sfera obrzędowości, zwyczajów świątecznych i rodzinnych).

Podsumowując, chciałbym podkreślić, że powstanie szkolnego słownika gwarowego przy wsparciu uniwersyteckim jest zadaniem przynoszącym wielorakie korzyści: edukacyjne, wychowawcze, społeczne, naukowe. Realizacja tego zadania angażuje uczniów do pracy na rzecz własnej społeczności, kontaktu z najbliższymi i integruje wiadomości z różnych działów wiedzy o języku i kulturze. Słownik dokumentuje stan języka dzisiejszej wsi i przekazuje go następnym pokoleniom. A wszystko to zaczyna się od rozmowy. 


\section{Bibliografia:}

Ambroziak Anna, Buchali Joanna, Czarnek Anna, Olszewska Paulina, 2010, Polska - nasz dom, nasz kraj. Edukacja patriotyczna i regionalna dzieci $w$ młodszym wieku szkolnym, w: Kowalska S. (red.), Rola elit społecznych w ochronie dziedzictwa kulturowego w społecznościach lokalnych, Poznań-Kalisz, s. 215-222.

Brzezińska Anna Weronika, 2006, W poszukiwaniu korzeni kulturowych, w: Brzezińska A.W., Hulewska A., Słomska J. (red.), Edukacja regionalna, Warszawa, s. 187-207.

Falińska Barbara, 2007, Uproszczona metoda ekspozycji słownictwa gwarowego z Podlasia i Suwalszczyzny, w: Cygan S. (red.), W kręgu dialektów i folkloru. Prace ofiarowane Doktor Teresie Gołębiowskiej, Docent Wandzie Pomianowskiej i Docent Zofii Stramirowskiej, Kielce, s. 71-88.

Grabka Barbara, Kucharzyk Renata, 2007, Dialekty i ich status w polskiej kulturze, w: Cygan S. (red.), W kręgu dialektów i folkloru. Prace ofiarowane Doktor Teresie Gołębiowskiej, Docent Wandzie Pomianowskiej i Docent Zofii Stramirowskiej, Kielce, s. 55-70.

Jędrysiak Tadeusz, 2010, Wiejska turystyka kulturowa, Warszawa.

Karaś Halina, 2013, Dialektologia a ochrona niematerialnego dziedzictwa kulturowego, w: Adamowski J., Smyk K. (red.), Niematerialne dziedzictwo kulturowe: źródła - wartości - ochrona, Lublin-Warszawa, s. 207-218.

Kąś Józef, 1998, Ortografia gwarowa a redakcja słownika gwarowego, w: Gala S. (red.), Teoretyczne, badawcze i dydaktyczne założenia dialektologii, Łódź, s. 323-329.

Kąś Józef, 2009, Słownik regionalny wśród słowników gwarowych, w: Dunaj B., Rak M., Polszczyzna mówiona ogólna i regionalna. Materiały ogólnopolskiej konferencji naukowej (Kraków, 25-26 września 2008 r.), Kraków, s. 11-19.

Kobus Justyna, Gniazdowski Tomasz (red.), 2018, Słownik języka mieszkańców okolic Gniezna. Święta, wierzenia i przesądy, Poznań.

Kobus Justyna, Stępień Magdalena (red.), 2018, Słownik języka mieszkańców okolic Czerniejewa. Praca na roli i w gospodarstwie, Poznań.

Kowalik Stanisław, 2006, Społeczność lokalna a kultura regionalna, w: Brzezińska A.W., Hulewska A., Słomska J. (red.), Edukacja regionalna, Warszawa, s. 21-45.

Osowski Błażej, 2016, Wykorzystanie metod jakościowych w badaniu gwary. Doświadczenia poznańskiego ośrodka dialektologicznego, w: Konieczka-Śliwińska D., Miedzińska I. (red.), Badania jakościowe $w$ regionalistyce, Poznań, s. 77-89.

Osowski Błażej (red.), 2018a, Gospodarz. Słownik języka mieszkańców powiatu kolskiego, Poznań.

Osowski Błażej (red.), 2018b, Gospodyni. Słownik języka mieszkańców powiatu kolskiego, Poznań.

Pelcowa Halina, 2013, Gwara jako nośnik lokalnego i regionalnego dziedzictwa kulturowego, w: Adamowski J., Smyk K. (red.), Niematerialne dziedzictwo kulturowe: źródła - wartości - ochrona, Lublin-Warszawa, s. 219-229. 
Podemska-Kałuża Anna, 2010, Edukacja regionalna na godzinach polskiego w szkole ponadgimnazjalnej - próba diagnozy, w: Kowalska S. (red.), Rola elit społecznych w ochronie dziedzictwa kulturowego w społecznościach lokalnych, Poznań-Kalisz, s. 165-178.

Sierociuk Jerzy, 2002, O swoistości pozyskiwania materiału w dialektologicznych badaniach leksyki i słowotwórstwa, w: Gala S. (red.), Dialektologia jako dziedzina językoznawstwa i przedmiot dydaktyki. Księga jubileuszowa dedykowana Profesorowi Karolowi Dejnie, Łódź, s. 483-488.

Sierociuk Jerzy, 2006, Regionalny słownik gwarowy - nowa propozycja z udziałem środowiska lokalnego, w: Bałachowicz J., Frycie S. (red.), Język - literatura - wychowanie. Praca zbiorowa dedykowana Profesor Annie Kowalskiej, Warszawa, s. 65-70.

Sierociuk Jerzy, 2007, Język mieszkańców wsi czy gwara? Problem nie tylko teoretyczny, „Prace Filologiczne”, t. 53, s. 527-534.

Sierociuk Jerzy, 2010, Założenia metodologiczne regionalnych słowników gwarowych powstajacych przy współudziale środowisk lokalnych, w: Kurek H., Tyrpa A., Wronicz J. (red.), Studia Dialektologiczne 4, Kraków, s. 135-143.

Sierociuk Jerzy (red.), 2019, Słownik języka mieszkańców ziemi łukowskiej. Praca na roli i $w$ gospodarstwie, Poznań.

Synowiec Helena, 2013, Śląska ojczyzna polszczyzna z perspektywy edukacyjnej. Wybór zagadnień, Katowice.

Wołek Monika, 2011, Rola edukacji regionalnej we współczesnej szkole, w: Wyżga M. (red.), Księgi metrykalne i inne źródła do historii lokalnej, ochrony i promocji lokalnego dziedzictwa kulturowego oraz tożsamości historycznej mieszkańców. Materiały z I Konferencji Naukowej Stowarzyszenia Korona Północnego Krakowa, Kraków-Raciborowice, s. 57-67.

Wronicz Jadwiga, 2007, Jak tworzyć amatorskie słowniki gwarowe?, w: Cygan S. (red.), W kręgu dialektów i folkloru. Prace ofiarowane Doktor Teresie Gołębiowskiej, Docent Wandzie Pomianowskiej i Docent Zofii Stramirowskiej, Kielce, s. 89-95.

Wronicz Jadwiga, 2013, Gwara jako element regionalnego dziedzictwa kulturowego, w: Adamowski J., Smyk K. (red.), Niematerialne dziedzictwo kulturowe: źródła - wartości - ochrona, Lublin-Warszawa, s. 231-237.

Żeromski Stefan, 2000, Snobizm i postęp, Gdańsk, (http://biblioteka.kijowski.pl/ zeromski\%20stefan/snobizm\%20i\%20postep.pdf. 27.01.2019).

\section{O Autorze:}

Błażej Osowski - dr, zajmuje się dialektologią współczesną i historyczną, związkami języka i regionu oraz słowiańskim kontekstem gwar polskich. Pracuje w Instytucie Filologii Polskiej Uniwersytetu im. Adama Mickiewicza w Poznaniu.

e-mail: blazej.osowski@amu.edu.pl 